ISSN: 1858-4837; E-ISSN: 2598-019X

Volume 15, Nomor 2 (2020),

https://jurnal.uns.ac.id/region

DOI: $10.20961 /$ region.v15i2.24138

\title{
Pengaruh jejaring industri lurik terhadap pengembangan Desa Wisata Tenun Tradisional Tlingsing, Klaten
}

\author{
The influence of lurik industrial network on the development of Tlingsing \\ Traditional Weaving Tourism Village, Klaten
}

\author{
N R Yudhasesa ${ }^{1}$, I Aliyah ${ }^{1}$, dan G Yudana ${ }^{1}$ \\ ${ }^{1}$ Program Studi Perencanaan Wilayah dan Kota, Fakultas Teknik, Universitas Sebelas \\ Maret
}

Corresponding author's email: nasarosaa@gmail.com

\begin{abstract}
Abstrak. Jejaring industri lurik tradisional merupakan suatu pola yang terbentuk berdasarkan aktivitas industri lurik tradisional yang dihubungkan dengan sistem transportasi, yang meliputi aktivitas pengadaan bahan baku, proses produksi hingga pemasaran. Aktivitas industri lurik tradisional berpengaruh terhadap keberlanjutan proses produksi tenun lurik tradisional di Desa Tlingsing. Desa Tlingsing pada tahun 2011 telah ditetapkan sebagai Desa Wisata Tenun Tradisional sehingga jejaring yang terbentuk berdasarkan aktivitas industri juga akan berdampak dengan pengembangan Desa Wisata Tenun Tradisional Tlingsing. Jumlah pengrajin lurik dan pengunjung Desa Wisata Tenun Tradisional Tlingsing dari tahun 2011-2017 mengalami peningkatan. Penelitian ini bertujuan untuk mengetahui pengaruh jejaring industri lurik tradisional terhadap pengembangan Desa Wisata Tenun Tradisional Tlingsing. Metode penelitian yang digunakan adalah analisis skoring dan analisis regresi linier berganda untuk mengetahui pengaruh jejaring industri lurik tradisional terhadap pengembangan Desa Wisata Tenun Tradisional Tlingsing. Berdasarkan analisis regresi linier berganda didapatkan hasil tingkat pengaruh jejaring industri lurik tradisional terhadap pengembangan Desa Wisata Tenun Tradisional Tlingsing dari pengaruh lemah - kuat yaitu (1) dekat dengan jalan raya dan fasilitas transportasi, (2) rumah makan, (3) toko cinderamata, (4) pusat informasi, (5) atraksi unik, (6) moda transportasi, (7) rambu jalan, (8) akomodasi, (9) ATM, dan (10) adanya masyarakat atau organisasi pengelola desa wisata.
\end{abstract}

Kata Kunci: Aktivitas Industri; ATBM; Industri Kreatif; Pengaruh; Pengembangan Desa Wisata; Jejaring

Received: September 21, 2018; Accepted: October 11, 2018; Available online: July 31, 2020

Copyright $\odot$ 2020, REGION: Jurnal Pembangunan Wilayah dan Perencanaan Partisipatif 


\begin{abstract}
The lurik traditional industries networking is formed based on the activities of the traditional lurik industry that is linked to the transportation system, which includes the activities of raw material procurement, production processes, up to marketing. Those activities influence the production process sustainability of traditional lurik weaving in the Tlingsing Village. In 2011, Tlingsing Village was established as a Traditional Weaving Tourism Village, so that the network formed based on industrial activities will also have an impact on the development of the Tlingsing Tourism Village. The number of lurik craftsmen and visitors of Tlingsing tourism villages from 2011-2017 has increased. This study aims to analyze the influence of traditional lurik industries network on the development of Tlingsing tourism villages. This research used scoring and multiple linear regression analysis to analyze the influence of traditional lurik industry network on the development of Tlingsing tourism village. Based on multiple linear regression analysis, the influence level of traditional lurik industry network on Tlingsing tourism village development from weak into strong are: (1) close to highways and transportation facilities, (2) restaurants, (3) souvenir shops, (4) information center, (5) unique attractions, (6) modes of transportation, (7) road signs, (8) accommodation, (9) ATM's, and (10) existency of community or village tourism management organizations.
\end{abstract}

Keywords: ATBM; Creative Industry; Industrial Activity; Influence; Network; Tourism Village Development

\title{
1. Pendahuluan
}

Salah satu wilayah di Indonesia yang berhasil mengembangkan Industri Kecil Menengah (IKM) sebagai hasil produk unggulan wilayahnya adalah Kabupaten Klaten. Berdasarkan PDRB Kabupaten Klaten tahun 2014, terdapat 3 sektor yang tingkat pertumbuhannya paling tinggi yaitu sektor perdagangan, hotel dan restoran sebanyak $30,70 \%$, industri pengolahan sebesar 20,34\%, serta sektor jasa-jasa sebesar 15,76\%. Menurut Data Industri Kecil dan Potensi Sentra Tahun 2008 Kabupaten Klaten (2008), Kabupaten Klaten adalah salah satu kabupaten di Jawa Tengah yang memiliki IKM cukup banyak yaitu berkisar 33.221 IKM [1]. IKM ini yang menjadikan industri jenis lurik menjadi salah satu produk unggulan dan ciri khas di Kabupaten Klaten dikarenakan masih menggunakan Alat Tenun Bukan Mesin atau yang biasa disebut dengan ATBM. Keberadaan pengrajin tenun ATBM semakin meningkat dan tersebar di beberapa kecamatan seperti Bayat, Cawas dan juga Pedan. Dari beberapa wilayah tersebut Kecamatan Cawas merupakan yang paling berkembang dan terdapat aglomerasi industri tenun ATBM yang berada di Desa Tlingsing. Kemudian pada tahun 2011, melalui Keputusan Bupati Klaten bahwa ditetapkannya Desa Tlingsing sebagai Desa Wisata Tenun ATBM Lurik di Kabupaten Klaten. Desa Tlingsing ini berkembang menjadi desa wisata minat khusus dengan ciri khas industri tenun lurik ATBM.

Rantai aktivitas industri lurik tradisional mulai dari pengadaan bahan baku hingga pemasaran yang sesuai dengan teori rantai aktivitas industri kreatif yang ada akan membentuk sebuah pola aktivitas, kemudian untuk mengetahui jejaring industri lurik dihasilkan dari proses pendistribusian bahan baku dan produk serta didukung dengan transportasi yang ada untuk kelancaran aktivitas industri. Dari aktivitas tersebut dapat membentuk sebuah jejaring 
secara spasial, sehingga jejaring dapat didefinisikan sebagai penghubung (link) antar simpul dalam suatu sistem transportasi [2].

Setiap proses pembuatan tenun ATBM dari pengadaan bahan baku hingga pemasaran serta seluruh komponen aktivitas industri kreatif pembuatan tenun lurik ATBM tersebut mendukung keberlanjutan industri lurik tradisional Desa Tlingsing yang dapat mendukung pengembangan Desa Wisata Tenun Tradisional Tlingsing. Proses produksi kreatif pembuatan tenun lurik tradisional tersebut didukung oleh individu terampil dan kreatif yang berdomisili di Desa Tlingsing sebagai pengrajin sehingga proses produksi dan produk yang dihasilkan juga kreatif. Pada proses produksi kreatif dimanfaatkan sebagai daya tarik wisata Desa Tlingsing yang berupa wisata edukasi sehingga wisatawan dapat menikmati dan mencoba proses pembuatan tenun lurik tradisional secara langsung serta pada proses produksi juga memanfaatkan teknologi dalam pencarian informasi dan komunikasi untuk mendukung keberjalanan proses produksi, dan produk kreatif yang dihasilkan dapat menjadi souvenir untuk wisatawan. Berdasarkan setiap proses pembuatan tenun ATBM serta seluruh komponen aktivitasnya memiliki potensi untuk mendukung pengembangan Desa Wisata Tenun Tradisional Tlingsing. Sehingga memunculkan pertanyaan: Bagaimana pengaruh jejaring industri lurik tradisional terhadap pengembangan Desa Wisata Tenun Tradisional Tlingsing?

\section{Metode}

Ruang lingkup wilayah pada penelitian ini yaitu Desa Tlingsing, Kecamatan Cawas, Kabupaten Klaten. Di Kabupaten Klaten aglomerasi tenun tradisional terbanyak berada pada Kecamatan Cawas dimana desa yang merupakan lokasi sentra industri lurik tradisional terletak di Desa Tlingsing, Mlese, Burikan dan Tirtomarto, namun untuk desa yang sudah ditetapkan sebagai desa wisata yaitu hanya Desa Tlingsing. Berikut peta lokasi lurik tradisional Desa Tlingsing dapat dilihat pada Gambar 1.

\subsection{Pendekatan dan jenis penelitian}

Pada penelitian ini menggunakan pendekatan penelitian deduktif. Pendekatan deduktif yaitu pendekatan yang digunakan pada penelitian dengan tujuan menguji teori mengenai suatu fenomena. Fenomena pada penelitian ini yaitu terkait dengan pengaruh jejaring yang ditimbulkan dari simpul aktivitas industri lurik terhadap pengembangan Desa Wisata Tenun Tradisional Tlingsing. Pada penelitian ini menggunakan jenis penelitian kuantitatif. Dalam penelitian ini dilakukan identifikasi industri lurik tradisional terhadap kondisi eksisting industri lurik tradisional Desa Tlingsing melalui metode skoring, kemudian mengidentifikasi pengembangan Desa Wisata Tenun Tradisional Tlingsing juga menggunakan metode skoring. Selanjutnya, untuk mengetahui pengaruh antar variabel jejaring industri lurik tradisional dengan variabel pengembangan desa wisata dilakukan analisis regresi linier berganda untuk mendapatkan tingkat pengaruh variabel jejaring industri lurik tradisional terhadap variabel pengembangan Desa Wisata Tenun Tradisional Tlingsing.

Populasi pada penelitian ini adalah pengrajin industri lurik tradisional di Desa Tlingsing, dengan pertimbangan pengrajin terlibat langsung dalam proses produksi lurik selain itu para 
pengrajin tersebut sebagai penyedia produk dan jasa serta sebagai pengelola Desa Wisata Tenun Tradisional Tlingsing. Sedangkan total sampel yang digunakan adalah 151 pengrajin hasil dari perhitungan sampel di setiap dukuhnya.

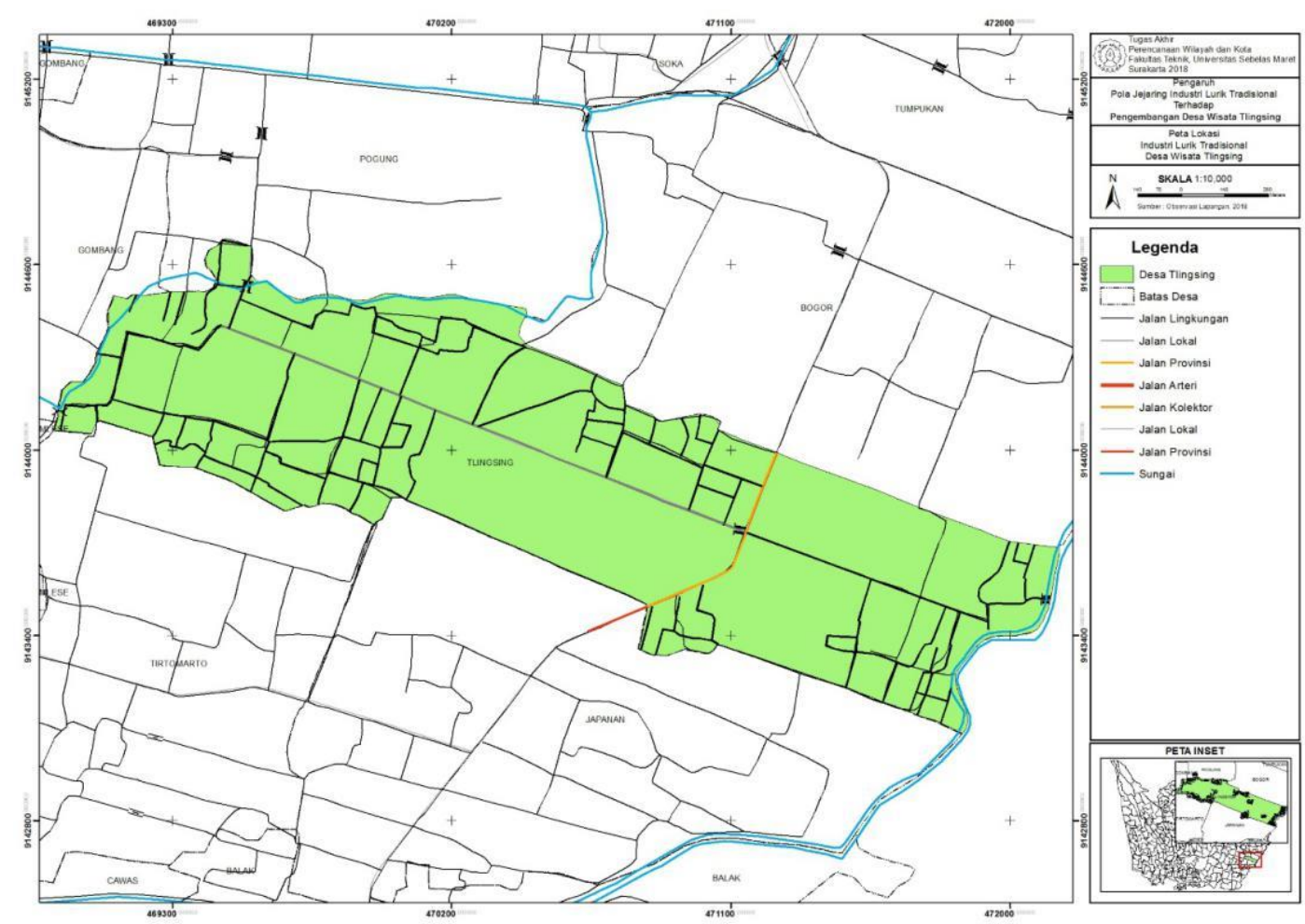

Gambar 1. Peta lokasi lurik tradisional Desa Tlingsing.

\subsection{Teknik analisis}

2.2.1 Identifikasi pola persebaran industri lurik tradisional. Analisis yang digunakan untuk mengetahui pola persebaran industri yaitu dengan analisis tetangga terdekat, adapun rumus yang digunakan yaitu:

$$
T=\frac{\overline{j_{u}}}{\overline{j_{h}}}
$$

Keterangan:

$\mathrm{T} \quad$ : indeks penyebaran tetangga terdekat

$\overline{\eta_{u}} \quad$ : jarak rata-rata yang diukur antara satu titik dengan titik tetangganya yang terdekat

$\overline{\boldsymbol{J}_{h}} \quad$ : jarak rata-rata yang diperoleh andai kata semua titik mempunyai pola random $=\frac{1}{2 \sqrt{p}}$

p : kepadatan $=\frac{j \text { iumlah benda }(N)}{\text { lual }(N \text { ang diobservasi }(A)}$ 
Setelah diketahui nilai $\mathrm{T}$, kemudian diinterpretasikan dengan klasifikasi analisis tetangga terdekat menurut Huggest dalam Bintarto dan Surastopo Hadisumarno [3] seperti pada Tabel 1:

Tabel 1. Rentang nilai perhitungan analisis tetangga terdekat [3].

\begin{tabular}{|c|c|}
\hline Rentang Nilai & Jenis Pola Penyebaran \\
\hline $0,00-0,70$ & Pola Mengelompok (clustered) \\
\hline $0,71-1,40$ & Pola Acak (random) \\
\hline $1,41-2,1491$ & Pola Seragam (reguler) \\
\hline
\end{tabular}

2.2.2 Identifikasi jejaring industri lurik tradisional. Identifikasi dilakukan pada variabel-sub variabel yang dapat dilihat pada Tabel 2. Berdasarkan tingkatan yang didapatkan dari masing-masing indikator tiap sub variabel, kemudian dilakukan analisis skoring dengan tahapan seperti pada Gambar 2.

Tabel 2. Variabel dan sub variabel jejaring industri lurik tradisional [4-19].

\begin{tabular}{|c|c|c|c|c|}
\hline Aspek & Variabel & Sub Variabel & Definisi Operasional & Sumber \\
\hline \multirow{8}{*}{$\begin{array}{l}\text { Jejaring } \\
\text { industri } \\
\text { lurik } \\
\text { tradisio } \\
\text { nal }\end{array}$} & \multirow[t]{4}{*}{ Bahan Baku } & $\begin{array}{l}\text { Cara } \\
\text { menghimpun } \\
\text { bahan baku }\end{array}$ & $\begin{array}{l}\text { Bahan baku dapat diperoleh secara } \\
\text { langsung dari produsen atau diperoleh } \\
\text { melalui perantara (pemasok) maupun } \\
\text { diproduksi sendiri }\end{array}$ & {$[4-5]$} \\
\hline & & $\begin{array}{l}\text { Lokasi bahan } \\
\text { baku }\end{array}$ & $\begin{array}{l}\text { Lokasi bahan baku berasal dari lokal } \\
\text { kawasan sehingga tidak jauh dari } \\
\text { lokasi industri }\end{array}$ & [6-7] \\
\hline & & $\begin{array}{l}\text { Jarak menuju } \\
\text { lokasi bahan } \\
\text { baku }\end{array}$ & $\begin{array}{l}\text { Jarak yang tidak terlalu jauh dari lokasi } \\
\text { proses produksi sehingga mudah } \\
\text { dijangkau dan biaya transportasi yang } \\
\text { dikeluarkan sedikit }\end{array}$ & [8-9] \\
\hline & & $\begin{array}{l}\text { Moda } \\
\text { transportasi } \\
\text { menuju lokasi } \\
\text { bahan baku }\end{array}$ & $\begin{array}{l}\text { Moda trasnportasi untuk mengangkut } \\
\text { bahan/barang menuju lokasi industri } \\
\text { guna keberlangsungan proses } \\
\text { produksi }\end{array}$ & [10] \\
\hline & \multirow[t]{4}{*}{$\begin{array}{l}\text { Proses } \\
\text { Produksi }\end{array}$} & $\begin{array}{l}\text { Individu } \\
\text { kreatif }\end{array}$ & $\begin{array}{l}\text { Proses produksi yang melibatkan } \\
\text { individu/tenaga kerja terampil }\end{array}$ & [10-11] \\
\hline & & $\begin{array}{l}\text { Proses } \\
\text { produksi } \\
\text { kreatif }\end{array}$ & $\begin{array}{l}\text { Sebuah rangkaian kegiatan selama } \\
\text { proses penciptaan barang dalam } \\
\text { pengembangan suatu produk }\end{array}$ & [12-14] \\
\hline & & Produk kreatif & $\begin{array}{l}\text { Produk yang dihasilkan dari adanya } \\
\text { inovasi pelaku usaha untuk } \\
\text { menciptakan produk yang berciri khas } \\
\text { budaya lokal pada wilayah produksi } \\
\text { dengan menekankan orisinalitas. }\end{array}$ & [15-16] \\
\hline & & Teknologi & $\begin{array}{l}\text { Pemanfaatan teknologi yang } \\
\text { digunakan dalam pencarian informasi } \\
\text { dan komunikasi yang mendukung }\end{array}$ & [17] \\
\hline
\end{tabular}




\begin{tabular}{|c|c|c|c|c|}
\hline Aspek & Variabel & Sub Variabel & Definisi Operasional & Sumber \\
\hline & & & keberjalanan proses produksi & \\
\hline & \multirow[t]{2}{*}{ Pemasaran } & Promosi & $\begin{array}{l}\text { Promosi dilakukan supaya mendorong } \\
\text { efektifitas dan efisien komunikasi } \\
\text { pada pemasaran }\end{array}$ & [18] \\
\hline & & $\begin{array}{l}\text { Distribusi } \\
\text { Produk }\end{array}$ & $\begin{array}{l}\text { Lokasi pasar yang optimal adalah } \\
\text { pasar yang terletak dekat dengan } \\
\text { lokasi produksi namun memiliki } \\
\text { jangkauan pemasaran yang luas serta } \\
\text { terdapat moda transportasi menuju } \\
\text { pasar sehingga dapat menarik minat } \\
\text { pembeli }\end{array}$ & {$[10,19]$} \\
\hline
\end{tabular}
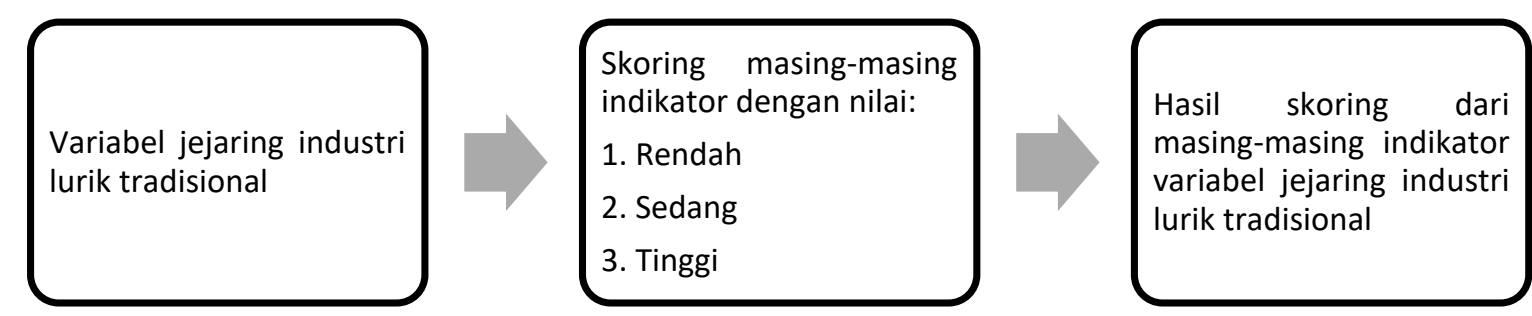

Gambar 2. Tahapan teknik analisis skoring jejaring industri lurik tradisional.

2.2.3 Identifikasi pengembangan Desa Wisata Tenun Tradisional Tlingsing. Identifikasi dilakukan pada variabel-sub variabel yang dapat dilihat pada Tabel 3. Berdasarkan tingkatan yang didapatkan dari masing-masing indikator, kemudian dilakukan analisis skoring dengan tahapan seperti pada Gambar 3.

Tabel 3. Variabel dan sub variabel pengembangan Desa Wisata Tenun Tradisional Tlingsing [13-14, 19-25].

\begin{tabular}{|c|c|c|c|c|}
\hline Aspek & Variabel & Sub Variabel & Definisi Operasional & Sumber \\
\hline \multirow[t]{4}{*}{$\begin{array}{l}\text { Pengembangan } \\
\text { Desa Wisata }\end{array}$} & Atraksi & Atraksi unik & $\begin{array}{l}\text { Proses produksi sebagai } \\
\text { atraksi yang unik sebagai } \\
\text { wisata edukasi }\end{array}$ & [13-14] \\
\hline & Aksesibilitas & $\begin{array}{l}\text { Dekat dengan } \\
\text { fasilitas } \\
\text { transportasi }\end{array}$ & $\begin{array}{l}\text { Kemudahan untuk } \\
\text { menjangkau lokasi wisata dari } \\
\text { lokasi disekitarnya }\end{array}$ & {$[20-21]$} \\
\hline & & $\begin{array}{l}\text { Moda } \\
\text { transportasi } \\
\text { menuju lokasi } \\
\text { wisata }\end{array}$ & $\begin{array}{l}\text { Tingkat aksesibilitas sutu } \\
\text { kawasan dapat dilihat dari } \\
\text { ketersediaan sarana } \\
\text { penghubung }\end{array}$ & [19] \\
\hline & & $\begin{array}{l}\text { Rambu-rambu } \\
\text { jalan }\end{array}$ & $\begin{array}{l}\text { Tersedia rambu-rambu } \\
\text { penunjuk jalan menuju desa } \\
\text { wisata yang sesuai dengan } \\
\text { kriteria perlengkapan jalan }\end{array}$ & [22-23] \\
\hline
\end{tabular}




\begin{tabular}{|c|c|c|c|c|}
\hline Aspek & Variabel & Sub Variabel & Definisi Operasional & Sumber \\
\hline & \multirow[t]{5}{*}{ Amenitas } & Akomodasi & $\begin{array}{l}\text { Tersedianya akomodasi } \\
\text { penginapan bagi wisatawan } \\
\text { dalam menunjang desa wisata }\end{array}$ & {$[24]$} \\
\hline & & $\begin{array}{l}\text { Toko } \\
\text { Cinderamata }\end{array}$ & $\begin{array}{l}\text { Tersedianya showroom/toko } \\
\text { cinderamata dalam } \\
\text { menunjang desa wisata }\end{array}$ & \\
\hline & & $\begin{array}{l}\text { Pusat } \\
\text { Informasi }\end{array}$ & $\begin{array}{l}\text { Tersedianya pusat informasi } \\
\text { bagi wisatawan dalam } \\
\text { menunjang desa wisata }\end{array}$ & \\
\hline & & Rumah makan & $\begin{array}{l}\text { Tersedianya rumah makan } \\
\text { bagi wisatawan dalam } \\
\text { menunjang desa wisata }\end{array}$ & \\
\hline & & ATM & $\begin{array}{l}\text { Tersedianya sarana keuangan } \\
\text { berupa ATM/Bank dalam } \\
\text { menunjang desa wisata }\end{array}$ & \\
\hline & $\begin{array}{l}\text { Ancillary } \\
\text { service }\end{array}$ & $\begin{array}{l}\text { Masyarakat/or } \\
\text { ganisasi } \\
\text { pengelola desa } \\
\text { wisata }\end{array}$ & $\begin{array}{l}\text { Ketersediaan suatu organisasi } \\
\text { ataupun masyarakat untuk } \\
\text { mengurus dan mengelola desa } \\
\text { wisata }\end{array}$ & {$[25]$} \\
\hline
\end{tabular}

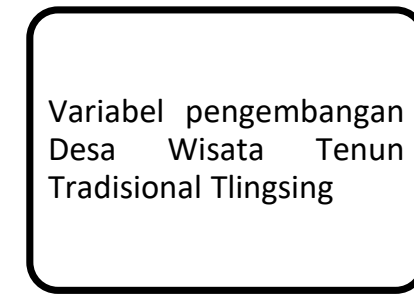

Skoring masing-masing
indikator dengan nilai:
1. Rendah
2. Sedang
3. Tinggi

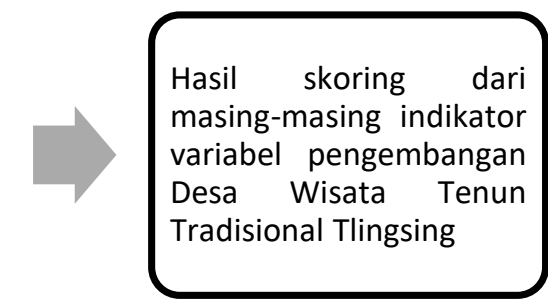

Gambar 3. Tahapan teknik analisis skoring pengembangan Desa Wisata Tenun Tradisional Tlingsing.

2.2.4 Analisis jejaring industri lurik tradisional terhadap pengembangan Desa Wisata Tenun Tradisional Tlingsing. Analisis ini dilakukan dengan teknik analisis regresi linier berganda untuk menguji pengaruh variabel independen terhadap variabel dependen secara simultan [26]. Kerangka analisis tersebut dapat dilihat pada Gambar 4. Hal itu ditunjukkan melalui koefisien determinasi $\left(R^{2}\right)$ yang memiliki nilai $0 \leq R^{2} \leq 1$. Apabila nilai mendekati 1 artinya berpengaruh sempurna atau memiliki kecocokan antar variabel, namun apabila nilai R2 mendekati atau sama dengan 0 maka tidak terdapat pengaruh atau kecocokan antar variabel. Berikut merupakan klasifikasi nilai R2 menurut Chin dalam Puspasari [27] yang tertera pada Tabel 4: 
Tabel 4. Klasifikasi $R^{2}$ [27].

\begin{tabular}{ccc}
\hline No & Nilai R2 & Keterangan \\
\hline 1 & $0-0,33$ & Pengaruh Lemah \\
2 & $0,34-0,66$ & Pengaruh Sedang \\
3 & $0,67-1$ & Pengaruh Kuat \\
\hline
\end{tabular}
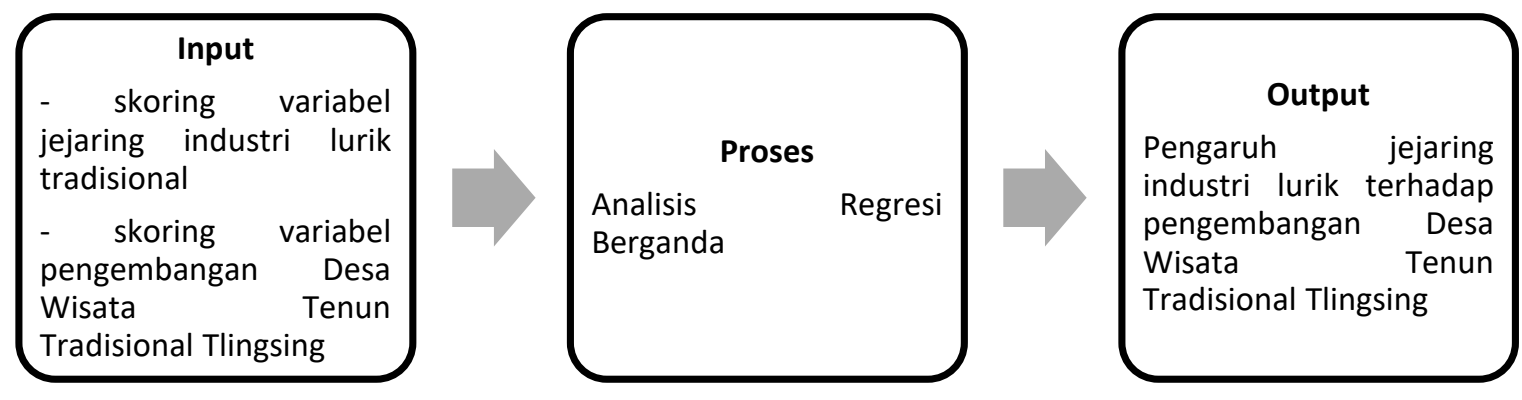

Gambar 4. Kerangka analisis penelitian.

\section{Hasil Penelitian dan Pembahasan}

\subsection{Pola persebaran industri lurik tradisional}

Pola persebaran industri lurik di Desa Tlingsing, ditentukan berdasarkan teori indeks tetangga terdekat atau nearest neighborhood analysis. Hasil dari perhitungan indeks tetangga terdekat tahun 2018 menggunakan software Arcgis 10.1 yaitu 0,467819. Hal ini menunjukkan bahwa pola persebaran industri lurik tradisional di Desa Tlingsing termasuk ke dalam klasifikasi pola mengelompok atau clustered yang menggunakan teori pengelompokkan industri menurut Huggest dalam Bintarto dan Surastopo Hadisumarno [3].

\subsection{Jejaring industri lurik tradisional}

Tabel 5. Rekapitulasi hasil skoring variabel pengaruh jejaring industri lurik tradisional.

\begin{tabular}{|c|c|c|c|c|}
\hline Variabel & Sub Variabel & Indikator & & terangan \\
\hline \multirow[t]{3}{*}{$\begin{array}{l}\text { Bahan } \\
\text { baku }\end{array}$} & $\begin{array}{l}\text { Cara menghimpun } \\
\text { bahan baku }\end{array}$ & $\begin{array}{l}\text { Bahan baku diperoleh dan } \\
\text { diantarkan langsung oleh produsen }\end{array}$ & 3 & Tinggi \\
\hline & Lokasi bahan baku & $\begin{array}{l}\text { Lokasi bahan baku berada di lokal } \\
\text { kawasan yaitu di dalam Kecamatan } \\
\text { Cawas }\end{array}$ & 3 & Tinggi \\
\hline & $\begin{array}{l}\text { Jarak menuju } \\
\text { lokasi bahan baku }\end{array}$ & $\begin{array}{l}\text { Jarak optimal lokasi industri } \\
\text { menuju lokasi bahan baku adalah } \\
12 \mathrm{~km}\end{array}$ & 3 & Tinggi \\
\hline
\end{tabular}




\begin{tabular}{|c|c|c|c|c|}
\hline Variabel & Sub Variabel & Indikator & & erangan \\
\hline & $\begin{array}{l}\text { Moda transportasi } \\
\text { menuju lokasi } \\
\text { bahan baku }\end{array}$ & $\begin{array}{l}\text { Pengangkutan bahan baku optimal } \\
\text { menggunakan } 1 \text { jenis moda secara } \\
\text { langsung dan dapat mengangkut } \\
\text { seluruh barang sekaligus }\end{array}$ & 3 & Tinggi \\
\hline \multirow{7}{*}{$\begin{array}{l}\text { Proses } \\
\text { produksi }\end{array}$} & Individu kreatif & Asal tenaga kerja & 3 & Tinggi \\
\hline & & $\begin{array}{l}\text { Jumlah tenaga kerja rata-rata setiap } \\
\text { industri } 1-4 \text { orang }\end{array}$ & 1 & Rendah \\
\hline & & $\begin{array}{l}\text { Tenaga kerja terampil telah } \\
\text { memiliki pengakuan kompetensi } \\
\text { kerja setelah mengikuti pelatihan } \\
\text { kerja }\end{array}$ & 3 & Tinggi \\
\hline & $\begin{array}{l}\text { Proses produksi } \\
\text { kreatif }\end{array}$ & $\begin{array}{l}\text { Adanya pemanfaatan kegiatan pada } \\
\text { proses penciptaan produk baru } \\
\text { sebagai atraksi wisata yang } \\
\text { melibatkan pelaku usaha dan } \\
\text { pengunjung }\end{array}$ & 2 & Sedang \\
\hline & & $\begin{array}{l}\text { Menerapkan strategi di dalam } \\
\text { pengembangan suatu produk }\end{array}$ & 3 & Tinggi \\
\hline & Produk kreatif & $\begin{array}{l}\text { Produk industri lurik tradisional } \\
\text { yang memiliki: 1) Inovasi, 2) ciri } \\
\text { khas lokal wilayah produksi, 3) } \\
\text { orisinalitas }\end{array}$ & 3 & Tinggi \\
\hline & Teknologi & $\begin{array}{l}\text { Tersedia teknologi informasi dan } \\
\text { komunikasi pendukung proses } \\
\text { produksi }\end{array}$ & 2 & Sedang \\
\hline \multirow[t]{6}{*}{ Pemasaran } & Promosi & $\begin{array}{l}\text { Promosi dengan cara: } \\
\text { Iklan } \\
\text { Promosi penjualan } \\
\text { Acara dan pengalaman } \\
\text { Merancang program promosi }\end{array}$ & & \\
\hline & & $\begin{array}{l}\text { Pemasaran langsung menggunakan } \\
\text { telepon }\end{array}$ & 1 & Rendah \\
\hline & & Pemasaran online & & \\
\hline & & Penjualan dari mulut kemulut & & \\
\hline & & $\begin{array}{l}\text { Penjualan personal dengan } \\
\text { bertatap muka }\end{array}$ & & \\
\hline & Distribusi produk & $\begin{array}{l}\text { Lokasi pasar dekat dengan lokasi } \\
\text { produksi }\end{array}$ & 3 & Tinggi \\
\hline
\end{tabular}




\begin{tabular}{llllll}
\hline Variabel & Sub Variabel & \multicolumn{1}{c}{ Indikator } & & Keterangan \\
\hline & Pengangkutan produk secara & & \\
& optimal menggunakan 1 jenis moda & & \\
& secara langsung dan dapat 3 & Tinggi \\
& mengangkut seluruh barang & & \\
& sekaligus & & & & \\
& Jangkauan pemasaran produk & & \\
& dapat pas menjangkau & pasar 2 & Sedang \\
& internasional & & & \\
\hline
\end{tabular}

Berdasarkan Tabel 5, dapat dilihat bahwa karakter industri lurik tradisional di Desa Tlingsing yaitu terdapat dua indikator yang berkategori rendah yaitu pada indikator jumlah tenaga kerja dan promosi penjualan. Sedangkan tiga indikator menyatakan berkategori sedang yaitu pada indikator adanya pemanfaatan proses produksi sebagai atraksi wisata edukasi, teknologi dan jangkauan pemasaran produk. Kemudian 10 indikator lainnya termasuk kategori tinggi.

Jejaring industri lurik tradisional Desa Tlingsing yang terbentuk berdasarkan rantai aktivitas industrinya yaitu mulai dari pengadaan bahan baku, proses produksi, hingga pemasaran yang bersifat mengalir dan saling bersinergi antar komponennya. Sehingga rantai aktivitas industri kreatif yang terbentuk di Desa Tlingsing sesuai dengan teori yang dikemukakan oleh UNIDO [28] tentang komponen pokok pembentuk rantai aktivitas industri kreatif yaitu inputs, manufacturing, dan marketing.

\subsection{Pengembangan Desa Wisata Tenun Tradisional Tlingsing}

Tabel 6. Rekapitulasi hasil skoring variabel pengembangan Desa Wisata Tenun Tradisional Tlingsing.

\begin{tabular}{|c|c|c|c|c|}
\hline Variabel & Sub Variabel & Indikator & & angan \\
\hline Atraksi & Atraksi unik & $\begin{array}{l}\text { Kegiatan wisata yang } \\
\text { memanfaatkan proses produksi } \\
\text { sebagai atraksi wisata edukasi }\end{array}$ & 2 & Sedang \\
\hline \multirow[t]{3}{*}{ Aksesibilitas } & $\begin{array}{l}\text { Dekat dengan } \\
\text { jalan raya dan } \\
\text { fasilitas } \\
\text { transportasi }\end{array}$ & $\begin{array}{l}\text { Jarak ideal kawasan supaya mudah } \\
\text { dijangkau yaitu kurang dari } 30 \text { km } \\
\text { ditinjau dari lokasi jalan arteri, } \\
\text { stasiun, dan bandara }\end{array}$ & 2 & Sedang \\
\hline & $\begin{array}{l}\text { Moda } \\
\text { Trasportasi }\end{array}$ & $\begin{array}{l}\text { Minimal tersedia } 1 \text { moda } \\
\text { transportasi yang melalui Desa } \\
\text { Wisata Tenun Tradisional Tlingsing }\end{array}$ & 1 & Rendah \\
\hline & $\begin{array}{l}\text { Rambu-rambu } \\
\text { jalan }\end{array}$ & $\begin{array}{l}\text { Tersedianya rambu-rambu jalan di } \\
\text { ruas jalan menuju Desa Wisata } \\
\text { Tenun Tradisional Tlingsing }\end{array}$ & 1 & Rendah \\
\hline Amenities & Toko & Jarak lokasi cinderamata $<200$ meter & 2 & Sedang \\
\hline
\end{tabular}




\begin{tabular}{|c|c|c|c|c|}
\hline Variabel & Sub Variabel & Indikator & \multicolumn{2}{|c|}{ Keterangan } \\
\hline & Cinderamata & dari pusat sentra wisata & & \\
\hline & Pusat Informasi & $\begin{array}{l}\text { Jarak lokasi pusat informasi }<200 \\
\text { meter dari pusat sentra wisata }\end{array}$ & 2 & Sedang \\
\hline & Akomodasi & $\begin{array}{l}\text { Jarak lokasi akomodasi penginapan } \\
<200 \text { meter dari pusat sentra wisata }\end{array}$ & 1 & Rendah \\
\hline & Rumah Makan & $\begin{array}{l}\text { Jarak lokasi rumah makan }<300 \\
\text { meter dari pusat sentra wisata }\end{array}$ & 2 & Sedang \\
\hline & ATM & $\begin{array}{l}\text { Jarak lokasi Bank/ATM }<200 \text { meter } \\
\text { dari pusat sentra wisata }\end{array}$ & 1 & Rendah \\
\hline Ancillary service & $\begin{array}{l}\text { Masyarakat/org } \\
\text { anisasi } \\
\text { pengelola desa } \\
\text { wisata }\end{array}$ & $\begin{array}{l}\text { Terdapat partisipasi masyarakat dan } \\
\text { adanya organisasi khusus dalam } \\
\text { mengelola seluruh industri lurik } \\
\text { tradisional sebagai desa wisata }\end{array}$ & 3 & Tinggi \\
\hline
\end{tabular}

Berdasarkan Tabel 6, dapat dilihat bahwa karakter pengembangan Desa Wisata Tenun Tradisional Tlingsing hanya satu indikator yang termasuk kategori tinggi yaitu pada indikator masyarakat atau organisasi pengelola desa wisata. Serta lima indikator termasuk kategori sedang yaitu indikator atraksi unik, dekat dengan jalan raya dan fasilitas transportasi, toko cinderamata, pusat informasi, dan rumah makan serta empat indikator lainnya termasuk kategori rendah yaitu indikator moda transportasi, rambu-rambu jalan, akomodasi, dan Anjungan Tunai Mandiri (ATM).

Berpedoman pada teori komponen pengembangan desa wisata meliputi atraksi, aksesibilitas, amenitas, dan ancillary service [25], atraksi wisata di Desa Wisata Tenun Tradisional Tlingsing berupa proses produksi lurik tradisional mulai dari pemilihan bahan baku hingga pemotongan kain tenun lurik. Selain itu, atraksi pada Desa Wisata Tenun Tradisional Tlingsing juga telah menerapkan teori atraksi wisata menurut Yoeti [13] dimana proses produksi sebagai atraksi khusus berupa kebudayaan sebagai wisata edukasi yang melibatkan pengrajin sebagai pelaku usaha dan pengunjung.

Tingkat pengembangan Desa Wisata Tenun Tradisional Tlingsing dari aspek aksesibilitas dapat dinilai dari sisi dekat dengan jalan raya dan fasilitas transportasi, moda transportasi serta tersedianya rambu jalan menuju Desa Wisata Tenun Tradisional Tlingsing. Akses menuju Desa Wisata Tenun Tradisional Tlingsing dari jalan arteri terdekat dan stasiun Klaten yaitu berjarak $18 \mathrm{~km}$ namun berjarak $39 \mathrm{~km}$ dengan bandara terdekat. Berdasarkan hasil penelitian, upaya yang dilakukan dalam pengembangan Desa Wisata Tenun Tradisional Tlingsing dari segi dekat dengan jalan raya dan fasilitas transportasi masih tergolong sedang. Namun, masih belum sesuai dalam segi tersedianya moda transportasi dan rambu-rambu jalan menuju Desa Wisata Tenun Tradisional Tlingsing, hal tersebut dikarenakan belum adanya moda transportasi yang melewati kawasan serta belum tersedianya rambu-rambu penujuk jalan menuju Desa Wisata Tenun Tradisional Tlingsing. 
Dari aspek amenitas, belum semua upaya yang dilakukan untuk pengembangan Desa Wisata Tenun Tradisional Tlingsing. Hal ini dikarenakan hanya beberapa fasilitas amenitas seperti rumah makan, toko cinderamata serta pusat informasi yang tersedia untuk wisatawan dan dapat dijangkau dengan berjalan kaki dari lokasi pusat sentra Desa Wisata Tenun Tradisional Tlingsing namun untuk fasilitas akomodasi dan ATM belum tersedia di lokasi wisata.

Kemudian komponen terakhir pengembangan desa wisata yang dikemukakan oleh Cooper, et al. (1993) dalam [25] adalah aspek ancillary service. Dalam pengembangan Desa Wisata Tenun Tradisional Tlingsing, upaya dari aspek ancillary service telah dilakukan. Hal ini ditandai dengan adanya kelompok sadar wisata Desa Tlingsing dan pengawasan dari Dinas Pariwisata Kabupaten Klaten serta adanya masyarakat yang turut mengelola desa wisata.

Tidak semua komponen telah dilakukan upaya untuk pengembangan Desa Wisata Tenun Tradisional Tlingsing. Hanya pada aspek atraksi wisata dan ancillary service yang telah dilakukan upaya penuh dalam pengembangan Desa Wisata Tenun Tradisional Tlingsing. Untuk aspek aksesibilitas dan amenitas masih terdapat beberapa upaya dalam pengembangan Desa Wisata Tenun Tradisional Tlingsing. Hal tersebut yang mendasari bahwa pengembangan Desa Wisata Tenun Tradisional Tlingsing belum sepenuhnya sesuai dengan teori pengembangan desa wisata yang dikemukakan oleh Cooper, et al. (1993) dalam [25].

3.4 Pengaruh jejaring industri lurik tradisional terhadap pengembangan Desa Wisata Tenun Tradisional Tlingsing

Tabel 7. Rekapitulasi besaran pengaruh jejaring industri lurik tradisional terhadap pengembangan Desa Wisata Tenun Tradisional Tlingsing.

\begin{tabular}{|c|c|c|c|c|c|}
\hline No & Variabel X & Variabel Y & Nilai & Ket & erangan \\
\hline 1 & $\begin{array}{l}\text { - Jejaring } \\
\text { industri lurik } \\
\text { tradisional } \\
\text { - Cara } \\
\text { menghimpun } \\
\text { bahan baku } \\
\text { - Lokasi bahan } \\
\text { baku } \\
\text { - Jarak menuju } \\
\text { lokasi bahan } \\
\text { baku } \\
\text { - Moda } \\
\text { transportasi } \\
\text { menuju }\end{array}$ & $\begin{array}{l}\text { Dekat dengan } \\
\text { jalan raya dan } \\
\text { fasilitas } \\
\text { transportasi }\end{array}$ & 0,114 & $\begin{array}{l}\text { Jejaring industri } \\
\text { lurik tradisional } \\
\text { berpengaruh } \\
\text { sedang terhadap } \\
\text { atraksi unik pada } \\
\text { pengembangan } \\
\text { Desa Wisata } \\
\text { Tenun Tradisional } \\
\text { Tlingsing } \\
\text { Jejaring industri } \\
\text { lurik tradisional } \\
\text { berpengaruh } \\
\text { lemah terhadap } \\
\text { dekat dengan } \\
\text { jalan raya dan }\end{array}$ & $\begin{array}{l}\text { Berdasarkan hasil } \\
\text { koefisien determinan } \\
\text { atau } \mathrm{R} 2 \text { memiliki nilai } \\
0 \leq \mathrm{R} 2 \leq 1 \text {. Jika R2 } \\
\text { mendekati } 1 \text { artinya } \\
\text { variabel } \\
\text { berpengruh terhadap } \\
\text { variabel terikat } \\
\text { dengan sempurna } \\
\text { atau } \\
\text { kecocokan. Namun, } \\
\text { apabila R2 adalah nol } \\
\begin{array}{lr}\text { (0) artinya variabel } \\
\text { bebas } \\
\text { berpengaruh }\end{array}\end{array}$ \\
\hline
\end{tabular}




\begin{tabular}{|c|c|c|c|c|c|}
\hline \multirow[t]{3}{*}{ No } & \multirow{3}{*}{$\begin{array}{l}\text { Variabel } \mathbf{X} \\
\text { lokasi bahan } \\
\text { baku } \\
\text { - Asal tenaga } \\
\text { kerja }\end{array}$} & \multirow[t]{3}{*}{ Variabel Y } & \multirow{3}{*}{$\begin{array}{c}\text { Nilai } \\
\mathbf{R}^{2}\end{array}$} & \multicolumn{2}{|c|}{ Keterangan } \\
\hline & & & & $\begin{array}{l}\text { fasilitas } \\
\text { transportasi pada } \\
\text { pengembangan }\end{array}$ & $\begin{array}{lr}\text { memiliki } & \text { kecocokan } \\
\text { dengan } & \text { variabel } \\
\text { terikat. } & \end{array}$ \\
\hline & & & & $\begin{array}{l}\text { Desa Wisata } \\
\text { Tenun Tradisional } \\
\text { Tlingsing }\end{array}$ & $\begin{array}{lr}\text { Berikut merupakan } \\
\text { urutan pengaruh } \\
\text { variabel dari yang }\end{array}$ \\
\hline 3 & & $\begin{array}{l}\text { Moda } \\
\text { transportasi }\end{array}$ & 1 & $\begin{array}{l}\text { Jejaring industri } \\
\text { lurik tradisional } \\
\text { berpengaruh kuat } \\
\text { terhadap moda } \\
\text { transportasi pada } \\
\text { pengembangan }\end{array}$ & $\begin{array}{l}\text { terkecil: } \\
\text { 1. Dekat dengan jalan } \\
\text { raya dan fasilitas } \\
\text { transportasi }\end{array}$ \\
\hline & & & & $\begin{array}{l}\text { Desa Wisata } \\
\text { Tenun Tradisional } \\
\text { Tlingsing }\end{array}$ & \\
\hline 4 & $\begin{array}{l}\text { - Tenaga kerja } \\
\text { terampil } \\
\text { - Kegiatan } \\
\text { produksi } \\
\text { sebagai } \\
\text { atraksi }\end{array}$ & $\begin{array}{l}\text { Rambu-rambu } \\
\text { jalan }\end{array}$ & 1 & $\begin{array}{l}\text { Jejaring industri } \\
\text { lurik tradisional } \\
\text { berpengaruh kuat } \\
\text { terhadap rambu- } \\
\text { rambu jalan pada } \\
\text { pengembangan }\end{array}$ & $\begin{array}{l}\text { 2. Rumah makan } \\
\text { 3. Toko cinderamata } \\
\text { 4. Pusat informasi } \\
\text { 5. Atraksi unik } \\
\text { 6. Moda transportasi }\end{array}$ \\
\hline & $\begin{array}{l}\text { - Pengembang } \\
\text { an produk } \\
\text { - Produk }\end{array}$ & & & $\begin{array}{l}\text { Desa Wisata } \\
\text { Tenun Tradisional } \\
\text { Tlingsing }\end{array}$ & $\begin{array}{l}\text { 7. Rambu-rambu } \\
\text { jalan } \\
\text { 8. Akomodasi }\end{array}$ \\
\hline 5 & kreatif & Toko & 0,431 & Jejaring industri & 9. ATM \\
\hline & $\begin{array}{l}\text { - Teknologi } \\
\text { - Promosi } \\
\text { - Lokasi pasar } \\
\text { - Jangkauan } \\
\text { pasar }\end{array}$ & cinderamata & & $\begin{array}{l}\text { lurik tradisional } \\
\text { berpengaruh } \\
\text { sedang terhadap } \\
\text { toko cinderamata } \\
\text { pada } \\
\text { pengembangan }\end{array}$ & $\begin{array}{l}\text { 10. Adanya } \\
\text { masyarakat/ } \\
\text { organisasi } \\
\text { pengelola desa } \\
\text { wisata }\end{array}$ \\
\hline & $\begin{array}{l}\text { transportasi } \\
\text { pengangkutan } \\
\text { produk }\end{array}$ & & & $\begin{array}{l}\text { Desa Wisata } \\
\text { Tenun Tradisional } \\
\text { Tlingsing }\end{array}$ & \\
\hline 6 & & $\begin{array}{l}\text { Pusat } \\
\text { informasi }\end{array}$ & 0,431 & $\begin{array}{l}\text { Jejaring industri } \\
\text { lurik tradisional } \\
\text { berpengaruh } \\
\text { sedang terhadap } \\
\text { pusat informasi } \\
\text { pada } \\
\text { pengembangan }\end{array}$ & \\
\hline
\end{tabular}

Received: September 21, 2018; Accepted: October 11, 2018; Available online: July 31, 2020 255 


\begin{tabular}{|c|c|c|c|c|}
\hline No & Variabel X & Variabel Y & $\begin{array}{c}\text { Nilai } \\
\mathbf{R}^{\mathbf{2}}\end{array}$ & Keterangan \\
\hline & & & & Desa Wisata \\
\hline & & & & Tenun Tradisional \\
\hline & & & & Tlingsing \\
\hline \multirow[t]{9}{*}{7} & & Akomodasi & 1 & Jejaring industri \\
\hline & & & & lurik tradisional \\
\hline & & & & berpengaruh kuat \\
\hline & & & & terhadap \\
\hline & & & & akomodasi pada \\
\hline & & & & pengembangan \\
\hline & & & & Desa Wisata \\
\hline & & & & Tenun Tradisional \\
\hline & & & & Tlingsing \\
\hline \multirow[t]{10}{*}{8} & & Rumah makan & 0,176 & Jejaring industri \\
\hline & & & & lurik tradisional \\
\hline & & & & berpengaruh \\
\hline & & & & lemah terhadap \\
\hline & & & & rumah makan \\
\hline & & & & pada \\
\hline & & & & pengembangan \\
\hline & & & & Desa Wisata \\
\hline & & & & Tenun Tradisional \\
\hline & & & & Tlingsing \\
\hline \multirow[t]{9}{*}{9} & & ATM & 1 & Jejaring industri \\
\hline & & & & lurik tradisional \\
\hline & & & & berpengaruh kuat \\
\hline & & & & terhadap ATM \\
\hline & & & & pada \\
\hline & & & & pengembangan \\
\hline & & & & Desa Wisata \\
\hline & & & & Tenun Tradisional \\
\hline & & & & Tlingsing \\
\hline \multirow[t]{10}{*}{19} & & Masyarakat/ & 1 & Jejaring industri \\
\hline & & organisasi & & lurik tradisional \\
\hline & & pengelola & & berpengaruh kuat \\
\hline & & desa wisata & & terhadap \\
\hline & & & & masyarakat/ \\
\hline & & & & organisasi \\
\hline & & & & pengelola \\
\hline & & & & wisata pada \\
\hline & & & & pengembangan \\
\hline & & & & Desa Wisata \\
\hline
\end{tabular}




\begin{tabular}{|c|c|c|c|c|}
\hline No & Variabel X & Variabel Y & $\begin{array}{c}\text { Nilai } \\
\mathbf{R}^{2}\end{array}$ & Keterangan \\
\hline & & & & onal \\
\hline
\end{tabular}

Jejaring industri lurik tradisional yang terbentuk berdasarkan simpul aktivitas kegiatan industri akan mempengaruhi keberlanjutan kegiatan industri lurik tradisional dimana industri lurik tradisional Desa Tlingsing ini juga sebagai daerah wisata, sehingga keberlanjutan industri lurik tradisional juga akan mempengaruhi keberlanjutan wisata tenun tradisional di Desa Tlingsing.

Berdasarkan pada teori menurut Yoeti [13] yang dilihat dari 3 faktor, yaitu something to see, something to do dan something to buy. Desa Tlingsing yang merupakan sebuah desa dengan fungsi industri dan fungsi sebagai desa wisata. Pada desa tersebut faktor something to see dan something to do telah diterapkan, dimana industri lurik tradisional harus tetap berlangsung karena industri tersebut mempengaruhi atraksi wisata di Desa Tlingsing. Desa Tlingsing juga menerapkan faktor something to buy. Dimana industri lurik tradisional berlaku sebagai penyedia produk berupa tenun lurik yang telah dihasilkan dari hasil proses produksi yang telah dilakukan sebagai souvenir atau kerajinan yang dapat dijadikan oleh-oleh wisatawan. Dengan adanya hal tersebut, mengakibatkan munculnya fasilitas berbelanja berupa toko cinderamata atau showroom tenun lurik tradisional yang juga sebagai tempat bagi pengrajin industri lurik tradisional Desa Tlingsing. Teori tersebut juga didukung oleh Evans dalam Suparwoko [29] yang menyatakan bahwa dari segi industri kreatif, produk kerajinan yang dihasilkan dalam bentuk souvenir dapat dijual melalui sektor pariwisata di toko cinderamata, dimana wisatawan memperoleh buah tangan sebagai memorabilia terhadap daerah wisata tersebut.

Kemudian, merujuk pada teori menurut Diana, et al [30] tentang peran masyarakat terhadap industri kreatif yaitu masyarakat sebagai pengelola industri dan masyarakat sebagai sumber daya manusia yang kreatif dan inovatif dalam menghasilkan suatu produk kerajinan sehingga bernilai seni tinggi yang dapat menarik wisatawan untuk datang dan membeli. Dimana pengrajin yang berada di industri lurik tradisional Desa Tlingsing juga sebagai pelaku pengelola Desa Wisata Tenun Tradisional Tlingsing. Sehingga dari pernyataan tersebut menyatakan bahwa Desa Tlingsing yang sebagai industri lurik tradisional mempengaruhi munculnya ancillary service pada Desa Wisata Tenun Tradisional Tlingsing. Ancillary service yang dimaksudkan yaitu adanya masyarakat atau organisasi pengelola desa wisata.

Berdasarkan hasil di atas, dapat dilihat bahwa industri lurik tradisional berpengaruh kuat terhadap keberlanjutan atraksi, menculnya toko cinderamata dan munculnya ancillary service pada Desa Wisata Tenun Tradisional Tlingsing. Seperti yang dijelaskan pada Tabel 7, atraksi, toko cinderamata yang termasuk bagian dari aspek amenitas, serta ancillary service merupakan bagian dari pengembangan Desa Wisata Tenun Tradisional Tlingsing, sehingga untuk lebih mengembangkan Desa Wisata Tenun Tradisional Tlingsing tidak bisa mengabaikan aspek amenitas yang terdiri dari fasilitas rumah makan, akomodasi, pusat 
informasi dan ATM serta aspek aksesibilitas yang terdiri dari indikator dekat dengan jalan raya, tersedianya moda transportasi dan tersedianya rambu-rambu jalan menuju kawasan Desa Wisata Tenun Tradisional Tlingsing. Dimana aspek amenitas dan aspek aksesibilitas merupakan salah satu bentuk fasilitas fisik yang harus disediakan untuk menunjang pengembangan Desa Wisata Tenun Tradisional Tlingsing guna memenuhi kebutuhan wisatawan selama berada di lokasi wisata. Hal tersebut didukung dengan teori menurut Spillane (2000) dalam Abdulhaji dan Yusuf [26] mengungkapkan bahwa fasilitas fisik (physical facility) adalah sarana yang disediakan oleh pengelola obyek wisata untuk memberikan pelayanan atau kesempatan kepada wisatawan menikmatinya.

Hasil yang didapatkan dari pembahasan di atas, dapat disimpulkan bahwa industri lurik tradisional berpengaruh kuat terhadap keberlanjutan atraksi, menculnya toko cinderamata dan munculnya ancillary service pada Desa Wisata Tenun Tradisional Tlingsing. Atraksi, toko cinderamata yang termasuk bagian dari amenitas, serta ancillary service merupakan bagian dari pengembangan Desa Wisata Tenun Tradisional Tlingsing. Beberapa fasilitas pada aspek amenitas seperti tersedianya pusat informasi dan rumah makan untuk penyediaan kebutuhan wisatawan merupakan komponen pengembangan Desa Wisata Tenun Tradisional Tlingsing yang muncul tidak secara langsung dipengaruhi oleh industri lurik tradisional Desa Tlingsing namun muncul akibat kebutuhan guna pengembangan Desa Wisata Tenun Tradisional Tlingsing. Serta aspek amenitas lainnya seperti ATM, dan akomodasi serta aspek aksesibilitas tidak dipengaruhi secara kuat oleh keberadaan industri lurik tradisional, dikarenakan posisinya sebagai aspek pendukung dalam pengembangan desa wisata, seperti terlihat pada Gambar 5 berikut :

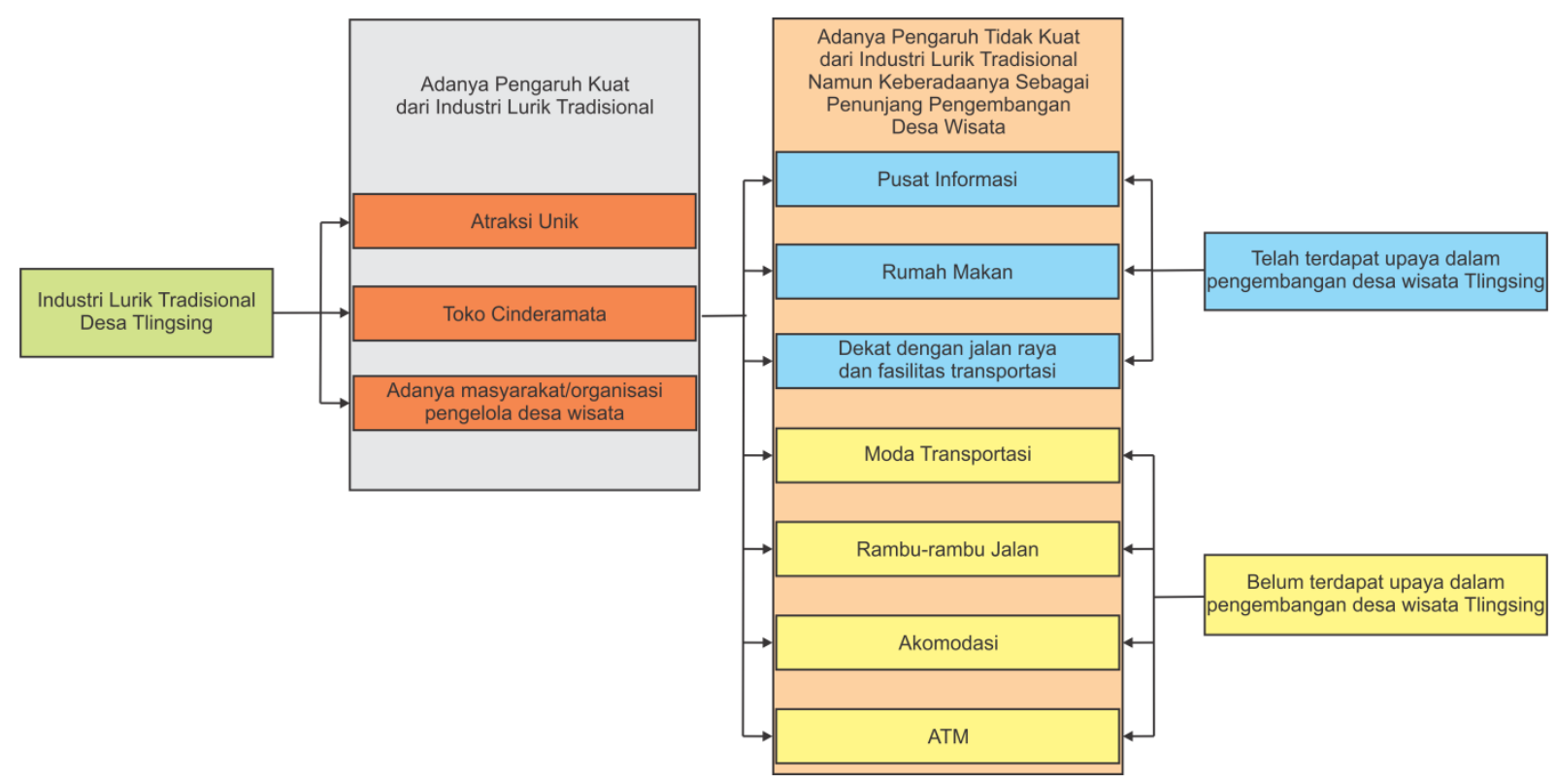

Gambar 5. Bagan pengaruh jejaring industri lurik terhadap pengembangan Desa Wisata

Tenun Tradisional Tlingsing berdasarkan teori. 
Namun berdasarkan hasil analisis menggunakan analisis regresi linier sebelumnya, pengaruh jejaring industri lurik tradisional terhadap pengembangan Desa Wisata Tenun Tradisional Tlingsing yang terbentuk dapat dilihat pada Gambar 6 sebagai berikut:

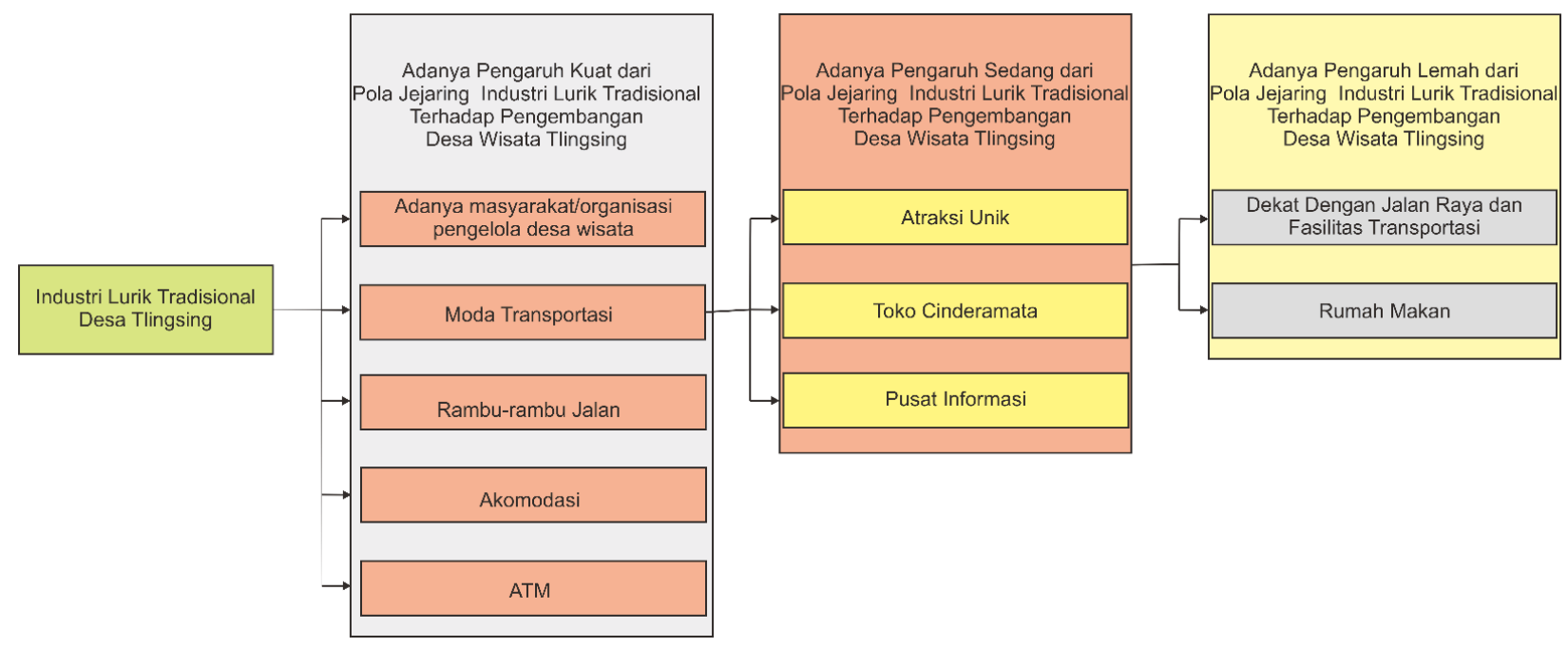

Gambar 6. Bagan hasil pengaruh industri lurik tradisional Desa Tlingsing terhadap pengembangan Desa Wisata Tenun Tradisional Tlingsing.

Ketika merujuk pada teori di atas dapat disimpulkan bahwa tingkat pengaruh yang ditimbulkan oleh jejaring industri lurik tradisional terhadap pengembangan Desa Wisata Tenun Tradisional Tlingsing masih belum sepenuhnya sesuai dengan teori-teori tersebut. Namun, semua indikator-indikator pengembangan Desa Wisata Tenun Tradisional Tlingsing di atas telah terdapat pengaruh yang ditimbulkan dari jejaring industri lurik tradisional Desa Tlingsing mulai dari pengaruh kuat hingga pengaruh lemah.

\section{Kesimpulan}

Berdasarkan hasil analisis tetangga terdekat didapatkan bahwa pola persebaran industri lurik tradisional di Desa Tlingsing yang terbentuk adalah pola mengelompok (clustered) berdasarkan Huggest dalam Bintarto dan Surastopo Hadisumarno [3].

Pengelompokan industri lurik tersebut terbentuk dari akibat wujud kebudayaan yang turun temurun sampai sekarang sehingga membentuk suatu pola kebiasaan aktivitas masyarakat. Berdasarkan simpul aktivitas industrinya yang membentuk rantai nilai aktivitas industri lurik tradisional yaitu dari mulai pengadaan bahan baku, proses produksi hingga pemasaran. Rantai nilai aktivitas tersebut didukung dengan transportasi yang ada untuk keberlangsungan dan kelancaran aktivitas industri, sehingga hal tersebut membentuk suatu jejaring industri lurik tradisional bersifat mengalir dan saling bersinergi antar komponennya.

Berjalannya rantai nilai aktivitas industri akan mempengaruhi upaya pengembangan Desa Wisata Tenun Tradisional Tlingsing yang dilakukan oleh masyarakat dan organisasi. Terdapat beberapa upaya pengembangan yang dilakukan untuk pengembangan Desa Wisata Tenun 
Tradisional Tlingsing yaitu pengembangan pada aspek atraksi wisata berupa wisata edukasi, aspek aksesibilitas, aspek amenitas, dan aspek ancillary service atau pengelolaan desa wisata oleh masyarakat dan organisasi. Perkembangan Desa Wisata Tenun Tradisional Tlingsing juga ditandai dengan bertambahnya pengrajin dan wisatawan baik mancanegara maupun wisatawan lokal pada setiap tahunnya.

Pengaruh yang dihasilkan industri lurik tradisional Desa Tlingsing terhadap pengembangan Desa Wisata Tenun Tradisional Tlingsing menghasilkan pengaruh kuat pada adanya masyarakat/organisasi pengelola desa wisata, moda transportasi, rambu-rambu jalan, akomodasi, dan ATM. Kemudian menghasilkan pengaruh sedang pada atraksi unik, toko cinderamata dan pusat informasi. Serta berpengaruh lemah terhadap subvariabel dekat dengan jalan raya dan fasilitas transportasi serta subvariabel rumah makan.

\section{Ucapan Terima Kasih}

Alhamdulillah, puji syukur kehadirat Allah SWT, dengan segala rezeki, nikmat dan karunianya penulis dapat menyelesaikan penelitian ini. Selain itu, penulis juga mengucapkan terimakasih atas bimbingan dan dukungan terhadap pihak yang berpartisipasi dan membantu penulis dalam menyelesaikan penelitian ini.

\section{Referensi}

[1] Data Industri Kecil dan Sentra Tahun 2008 Kabupaten Klaten. 2008. Klaten : Dinas Perindustrian Perdagangan Koperasi dan Penanaman Modal Kabupaten Klaten

[2] Santoso E B, Umilia E dan Aulia B U 2012 Diktat Analisis Lokasi dan Keruangan (RP091209) (Surabaya: Institut Teknologi Sepuluh Nopember) Diakses dari https://www.academia.edu/25097490/DIKTAT_ANALISIS_LOKASI_DAN_KERUANGA N_RP09-1209_ITS_Surabaya

[3] Bintarto R dan Hadisumarno S 1991 Metode Analisis Geografi (Jakarta: LP3ES)

[4] Baroto T 2002 Perencanaan dan Pengendalian Produksi (Jakarta: Ghalia Indonesia)

[5] Ahyari A 2003 Manajemen Produksi Perencanaan Sistem Produksi (Yogyakarta: BPFE UGM)

[6] Kholmi M 2003 Akuntansi Biaya (Yogyakarta: BPFE)

[7] Hoover dan Giarratani 2007) Economics of Location. Terjemahan oleh Nugroho dan Dahuri (Jakarta: Lembaga Penerbit UI Jakarta)

[8] Tamin O Z 2000 Perencanaan dan Permodelan Transportasi (Bandung: ITB)

[9] Zulkarnaen R R dan Setiawan R P 2013 Kriteria Lokasi Industri Pengolahan Pisang di Kabupaten Lumajang Jurnal Teknik Pomits 2 pp 1-6 Diakses dari https://docplayer.info/30137973-Kriteria-lokasi-industri-pengolahan-pisang-dikabupaten-lumajang.html

[10] Sjafrizal 2008) Ekonomi Regional, Teori dan Aplikasi (Padang: Baduose Media)

[11] Undang-Undang Nomor 13 Tahun 2003 tentang Ketenagakerjaan pasal 18

[12] Kotler P dan Keller 2007 Manajemen Pemasaran Jilid I Edisi Kedua belas (Jakarta: PT. Indeks)

[13] Yoeti O A 1990 Pengantar Ilmu Pariwisata (Bandung: Penerbit Angkasa Bandung) 
[14] Pokdarwis Tlingsing 2019 Komunikasi Personal

[15] Baron F 1969 Thinking Creatively (Mishawaka: Better Word Books)

[16] Munandar U 1999 Pengembangan Kreativitas Anak Berbakat. (Jakarta: Penerbit Rineka Cipta)

[17] Merdekawati A Z H, Soedwiwahjono dan Putri R A 2016 Kesesuaian Sentra Industri Batik Masaran Kabupaten Sragen Sebagai Sentra Industri Kreatif Kerajinan. Jurnal Pembangunan Wilayah dan Perencanaan Partisipatif 7 pp $59-71$ DOI: 10.20961/region.v7i2.11574

[18] Kotler dan Keller 2009 Manajemen Pemasaran (Jakarta: Erlangga)

[19] Tarigan R 2005 Perencanaan Pembangunan Wilayah (Jakarta: Bumi Aksara Jakarta)

[20] Sutanta 2010 Faktor-Faktor Penyebab Tidak Berkembangnya Kawasan Industri Nguter Kabupaten Sukoharjo Thesis Diakses dari http://eprints.undip.ac.id/24068/

[21] Dirdjojuwono R W 2014 Kawasan Industri Indonesia: Sebuah Konsep Perencanaan dan Aplikasinya (Bogor: Biografika)

[22] Peraturan Pemerintah Republik Indonesia Nomor 34 Tahun 2006 tentang Jalan

[23] Peraturan Menteri Pekerjaan Umum No 19 Tahun 2011 tentang Kriteria Perlengkapan Jalan

[24] SNI 03-1733-2004 tentang Tata Cara Perencanaan Lingkungan Perumahan di perkotaan

[25] Antara M dan Arida I N S 2015 Panduan Pengelolaan Desa Wisata Berbasis Potensi Lokal (Bali: Universitas Udayana) Diakses dari https://repositori.unud.ac.id/protected/storage/upload/repositori/8d500ce0c134ec 57aff5162cef879448.pdf

[26] Abdulhaji S dan Yusuf I S H 2016 Pengaruh Atraksi, Aksesibilitas, dan Fasilitas Terhadap Citra Objek Wisata Danau Tolire Besar di Kota Ternate Jurnal Penelitian Humano 72 pp 134-48 DOI: 10.33387/hjp.v7i2.317

[27] Puspasari N 2017. Pengaruh Kepemimpinan, Komunikasi Organisasi dan Partisipasi Karyawan Terhadap Kesiapan Karyawan Menghadapi Perubahan Lingkungan Bisnis (UKM Klaster Ekonomi Kreatif) Thesis Diakses dari https://repository.ipb.ac.id/handle/123456789/88746

[28] UNIDO 2007 Creative Industries and Micro \& Small Scale Enterprise Development Diakses dari https://www.unido.org/sites/default/files/200903/69264_creative_industries_0.pdf pada 11-07-2020

[29] Suparwoko I M P 2017 Pengembangan Ekonomi Kreatif Sebagai Penggerak Industri Pariwisata Conference: Simposium Nasional Diakses dari https://www.researchgate.net/publication/273122669_Pengembangan_Ekonomi_K reatif_Sebagai_Penggerak_Industri_Pariwisata_Kabupaten_Purworejo_Jawa_Tenga h

[30] Diana P, Suwena I K dan Wijaya N M S 2017 Peran dan Pengembangan Industri Kreatif Dalam Mendukung Pariwisata di Desa Mas dan Desa Peliatan, Ubud Jurnal Analisis $\begin{array}{lllllll}\text { Pariwisata } & 17 & 2 & \mathrm{pp} & 84-92 & \text { Diakses } & \text { dari }\end{array}$ https://ojs.unud.ac.id/index.php/jap/article/view/36485 